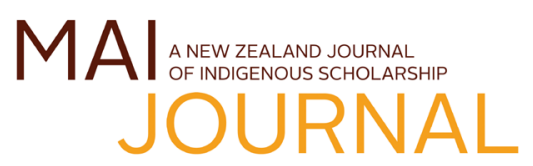

DOI: 10.20507/MAlJournal.2020.9.4.4

\title{
THE RELEVANCE OF TE TIRITI O WAITANGI IN THE COVID-19 ERA
}

\section{Claire Charters*}

\begin{abstract}
In this situation report I highlight how Te Tiriti o Waitangi is relevant to state and Māori regulation related to the COVID-19 pandemic, suggesting also that it was somewhat ignored by Aotearoa New Zealand's state institutions during the country's initial response. Focusing on the te reo text of Te Tiriti as the constitutionally and legally primary text of the Treaty of Waitangi, I argue, first, that Te Tiriti requires joint Māori and state regulation over the territories and peoples of Aotearoa New Zealand, including with respect to the COVID-19 pandemic. Second, Te Tiriti requires state government to regulate equitably and, third, it requires state government not to interfere unreasonably with taonga Māori and our culture. The government needs to do more in its COVID-19 regulatory response to comply with Te Tiriti, and therefore to act constitutionally and with legitimacy.
\end{abstract}

\section{Keywords}

Te Tiriti o Waitangi, rangatiratanga, governance, justice and rights

The COVID-19 era is like a fast-moving picture which perpetually develops and re-develops. The picture adjusts with ever-changing information on the relevant health science, the impact on the economy, the need for restrictions on movement, and the openness of our borders into the future. Where does our rock, New Zealand's constitutional foundation, Te Tiriti o Waitangi, fit in all of this? Right in the centre, together with $\mathrm{He}$ Whakaputanga o te Rangatiratanga o Nu Tireni I the Declaration of Independence (1835) and the United Nations Declaration on the Rights of Indigenous Peoples (United Nations, 2008; hereafter, "Indigenous Declaration").

First, Te Tiriti sets out who has authority to regulate Aotearoa New Zealand, her lands, territories and resources, and the peoples here. And regulation-in the form of laws, rules and poweris the tool of government to address and respond to COVID-19.
Te Tiriti tells us that the New Zealand state government has some kawanatanga, and that Māori have rangatiratanga, and that state law and Māori law both regulate peoples and territory here. We have seen numerous examples of this. In March-May 2020, the state issued new laws and rules under the Health Act 1956, the Epidemic Preparedness Act 2006 and other legislation, and then eventually specific legislation giving specific powers to ministers and officials: the COVID-19 Public Health Response Act 2020 (COVID-19 Act). Similarly, Māori continue to exercise their authority too, under tikanga Māori. They exercised it to restrict access to our communities, to provide flu vaccinations to our people, to feed our kaumātua, to educate our children and to provide personal protective equipment to our health providers ("How Māori," 2020).

As in any place where multiple legal systems are in play, which is true of all with Indigenous 
peoples, there needs to be coordination between laws and between the makers and the enforcers of the law. It was heartening to see the police and iwi working together on the East Coast, in Taranaki, in Northland, and in other places around the motu to enforce iwi rāhui and other restrictions on movement within their rohe (Johnston, 2020; Williams \& Harris, 2020).

On the other hand, it would have been good to see more effort by state government to work in partnership with Māori governments to jointly devise and implement strategies, under law, to address COVID-19. State funding to support Māori initiatives to respond to COVID-19 was welcomed, even if it might have come sooner. Coordinated governance would have been better, especially based on shared information and expertise, and an understanding of equally shared authority to regulate. Coordinated oversight of state governmental action would have been better, too, including more involvement of Māori in the Epidemic Response Committee (Hurihanganui, 2020). Most tellingly, so too would have greater and more influential Māori involvement in the development of the COVID-19 Act (Kelsey, 2020). Instead, most Māori who were approached were given only hours to comment, and some important contributions were rejected or ignored.

The Indigenous Declaration provides a blueprint for how Indigenous law and state law should co-exist. For example, Article 4 requires, as one expression of self-determination, Māori autonomy and self-government in local and internal affairs. This means that state law should not regulate matters that are fundamental to Māori. On the contrary, tikanga Māori should regulate internal Māori affairs.

I hope that the New Zealand Government will continue with its work towards a plan to realise the Indigenous Declaration and provide more detail on a postcolonial plural legal structure. We could have used such a plan during this emergency. The independent working group established by Cabinet to provide the government with advice on how to realise the Indigenous Declaration is still waiting for the government to respond to its report, coming up to nine months after delivering it.

Second, as Aotearoa's constituting and foundational treaty, Te Tiriti imposes restrictions on te Karauna. If state authority, and power, is not exercised in accordance with Te Tiriti-or human rights, or Indigenous peoples' rights-it is constitutionally illegal and illegitimate, even in times of emergency when restrictions can be somewhat relaxed (at least under state law).
The principle of equity is basic to Te Tiriti. What we know for sure is that Māori do not enjoy equity with non-Māori in today's Aotearoa. This is an unfortunate truth in many of the areas that are under pressure during this time: health, education, housing and criminal justice, and especially our prisons.

As my colleague and whanaunga Dr Elana Curtis (2020) points out, it behoves state government to focus on the impact of seemingly "neutral" COVID-19 strategies on Māori, for example, diverting care from patients with chronic illness, which Māori disproportionately experience. And, given our relatively high level of chronic illness, the state is required to take super-good care that COVID-19 does not come into high-density Māori communities, where the impact could be proportionately worse, as it has been in Indigenous communities in the United States and Brazil, for example.

Third, Te Tiriti protects Māori rights to taonga Māori, including our culture. How is this relevant during the COVID-19 pandemic? By way of example, it requires attention to how restrictions on movement and association might impact on Māori practising our culture, whether it be in relation to tangihanga or catching fish, or the ability to kaitiaki river or manaaki our manuhiri. Such restrictions, even if part of a general prohibition, are only legally justified if they are kept to the minimum level and for the shortest time necessary.

Looking ahead, state and Māori regulation continues and will continue in the post-COVID-19 period, and that regulation should also comply with Te Tiriti, as it should at all times. There is some cause for concern. The government has given itself a number of additional powers to enable it to restrict the movement of people in the unhappy case that COVID-19 returns, under the COVID-19 Act and associated legislation, including on marae. Marae are sovereign spaces for Māori, and it is questionable whether state government should have any authority there, ever. One can only hope that the government will not use that power unless it has the consent of the relevant tangata whenua of the rohe where the marae sits.

State government is also considering expedited processes to fast-track development in the Resource Management Act 1991 (RMA) and has introduced a short-term consenting process to achieve this under the COVID-19 Recovery (Fasttrack Consenting) Act 2020 (see Ministry for the Environment, 2020). Māori must be involved, and must have authority to provide their free, prior and informed consent to new and amended 
legislation that might impact us, and especially legislation that regulates our treasured lands, territories and resources. Ihumātao has illustrated the disastrous consequences that can follow when RMA provisions providing for Māori participation in decisions to develop are weakened (Human Rights Commission, 2019).

All of this is to say that, moving forward, state governmental institutions, from the prime minister to the officials carrying out Cabinet's and Parliament's rules, only act legitimately and legally when they conform to our constitutional lighthouse, Te Tiriti o Waitangi. This is especially true in times of constitutional stress, such as the emergency presented by the COVID-19 pandemic and its aftermath.

\section{Acknowledgement}

An earlier version of this situation report appeared in the News and Opinion section of the University of Auckland website on 19 April 2020. It is reprinted here with permission.

\section{Glossary}

\begin{tabular}{|c|c|}
\hline & Māori name for New Zealand \\
\hline iwi & tribe \\
\hline kaitiaki & protect \\
\hline kaumātua & elders \\
\hline kawanatanga & governance \\
\hline manaaki & to host \\
\hline manuhiri & guests \\
\hline marae & $\begin{array}{l}\text { complex of buildings around a } \\
\text { sacred open meeting area }\end{array}$ \\
\hline motu & country \\
\hline rāhui & $\begin{array}{l}\text { temporary ritual prohibitions, } \\
\text { bans }\end{array}$ \\
\hline rangatiratanga & $\begin{array}{l}\text { sovereign authority, } \\
\text { self-determination }\end{array}$ \\
\hline rohe & territory, region, district \\
\hline tangata whenua & $\begin{array}{l}\text { people of the land (Indigenous } \\
\text { people of Aotearoa) }\end{array}$ \\
\hline tangihanga & funeral rites \\
\hline taonga & treasures \\
\hline te reo & the Māori language \\
\hline te Karauna & the (British) Crown \\
\hline kanga & customs, practices, protocols \\
\hline hānaunga & relative, relation \\
\hline
\end{tabular}

\section{References}

Curtis, E. (2020, April 5). An open letter to the government from a Māori public health specialist. Spinoff. https://e-tangata.co.nz/comment-and-analysis/ an-open-letter-to-the-government-from-a-maoripublic-health-specialist/

How Māori across the country are working to stop the spread of Covid-19.(2020, March 26). RNZ. https:// www.rnz.co.nz/news/te-manu-korihi/412680/ how-maori-across-aotearoa-are-working-to-stopthe-spread-of-covid-19

Human Rights Commission. (2019, August 23). Internationalhumanrightsperspectives on Ihumātao. https:/www.hrc.co.nz/files/5115/6651/4254/ International_human_rights_perspectives_on_ Ihumatao.pdf

Hurihanganui, T. A. (2020, May 6). Simon Bridges ignored proposals for Māori and Epidemic Response Committee, MP says. RNZ. https:// www.rnz.co.nz/news/te-manu-korihi/415943/ simon-bridges-ignored-proposals-for-maori-atepidemic-response-committee-mp-says

Johnston, K. (2020, April 19). Whose land is it anyway? E-Tangata. https://e-tangata.co.nz/ comment-and-analysis/whose-land-is-it-anyway/

Kelsey, J. (2020, May 15). Govt's urgent legislation tone-deaf to Māori. NZ Herald. https://www.nzherald.co.nz/nz/news/article. cfm?c_id=1\&objectid $=12331815$

Ministry for the Environment. (2020, July 15). The COVID-19 Recovery (Fast-track Consenting) Act 2020. https://www.mfe.govt.nz/rma/ act-to-fast-track-projects

United Nations. (2008). United Nations Declaration of Indigenous Rights. https://www.un.org/esa/socdev/ unpfii/documents/DRIPS_en.pdf

Williams, D. V., \& Harris, M. (2020, May 10). Community checkpoints are an important and lawful part of NZ's Covid response. Spinoff. https://thespinoff.co.nz/society/10-05-2020/ community-checkpoints-an-important-and-lawfulpart-of-nzs-covid-response/ 